\title{
Spinal neurocytoma with extensive syringohydromyelia
}

\author{
Mohammad Hanafiah, ${ }^{1}$ Soo Fin Low, ${ }^{2}$ Radhika Sridharan, ${ }^{2}$ Benny Young ${ }^{3}$
}

${ }^{1}$ Radiology Department, MARA University of Technology Clinical Training Centre, Sungai Buloh, Selangor, Malaysia ${ }^{2}$ Department of Radiology, Universiti Kebangsaan Malaysia Medical Centre, Cheras, Kuala Lumpur, Malaysia

Radiology Department, Universiti Malaysia Sarawak, Kuching, Sarawak, Malaysia

\section{Correspondence to} Dr Mohammad Hanafiah, mhanafiah8804@gmail.com; bofot@yahoo.com
To cite: Hanafiah M, Low SF, Sridharan $R$, et al. BMJ Case Rep Published online: [please include Day Month Year] doi:10.1136/ bcr-2013-201285

\section{DESCRIPTION}

Neurocytoma of the spinal cord is extremely rare. We present the images of a spinal neurocytoma in a 34-year-old man who was presented with a 3-week history of worsening back pain associated with bilateral lower limb weakness. At presentation, the muscle power of both of the lower limbs was $3 / 5$.
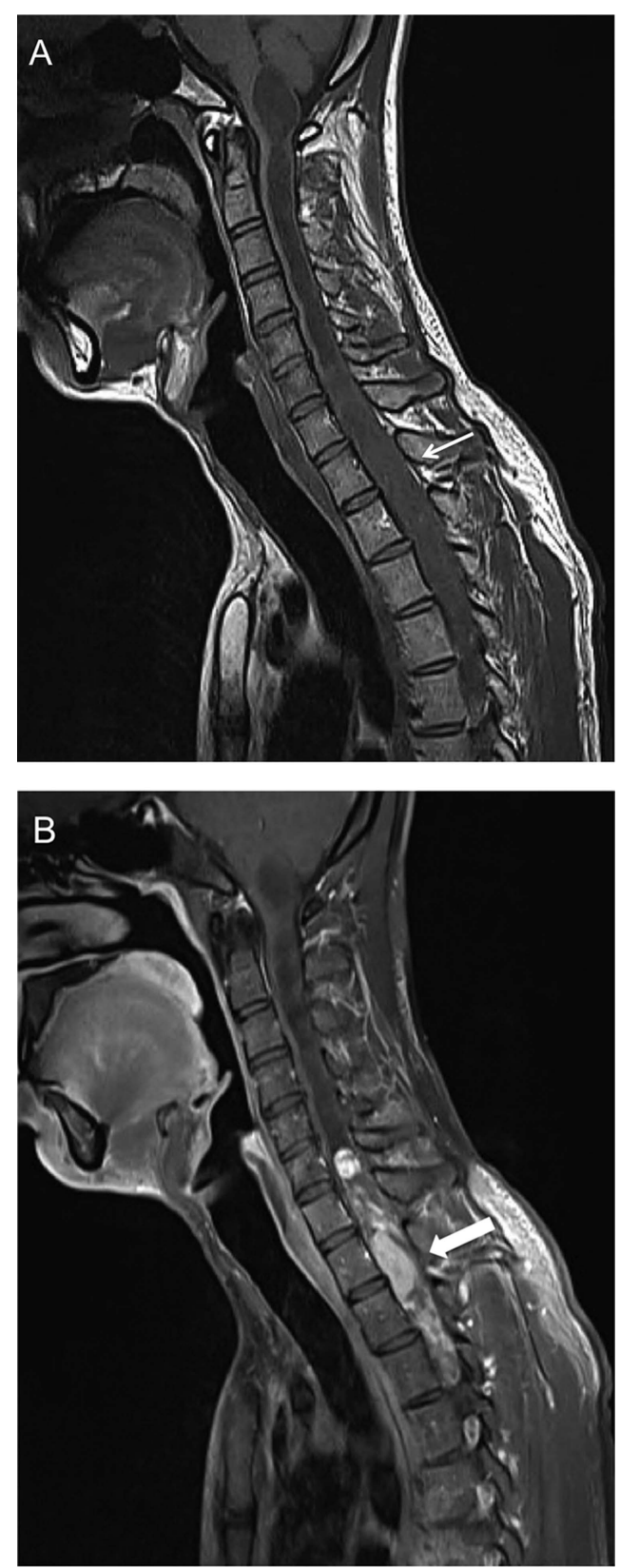

Figure 1 Sagittal MRI. The T1-weighted sequence (A) shows that the intramedullary lesion is isointense to the cord (thin arrow). On postgadolinium fat suppressed sequence (B), the lesion demonstrates heterogeneous and avid enhancement (thick arrow).
The deep tendon reflexes of the lower limb were brisk and the sensation of the right lower limb at L1 dermatome was reduced.

The routine blood investigations were unremarkable. MRI of the whole spine demonstrated a heterogeneously and avidly enhancing intramedullary mass extending from C6 to T4 level (figure 1)

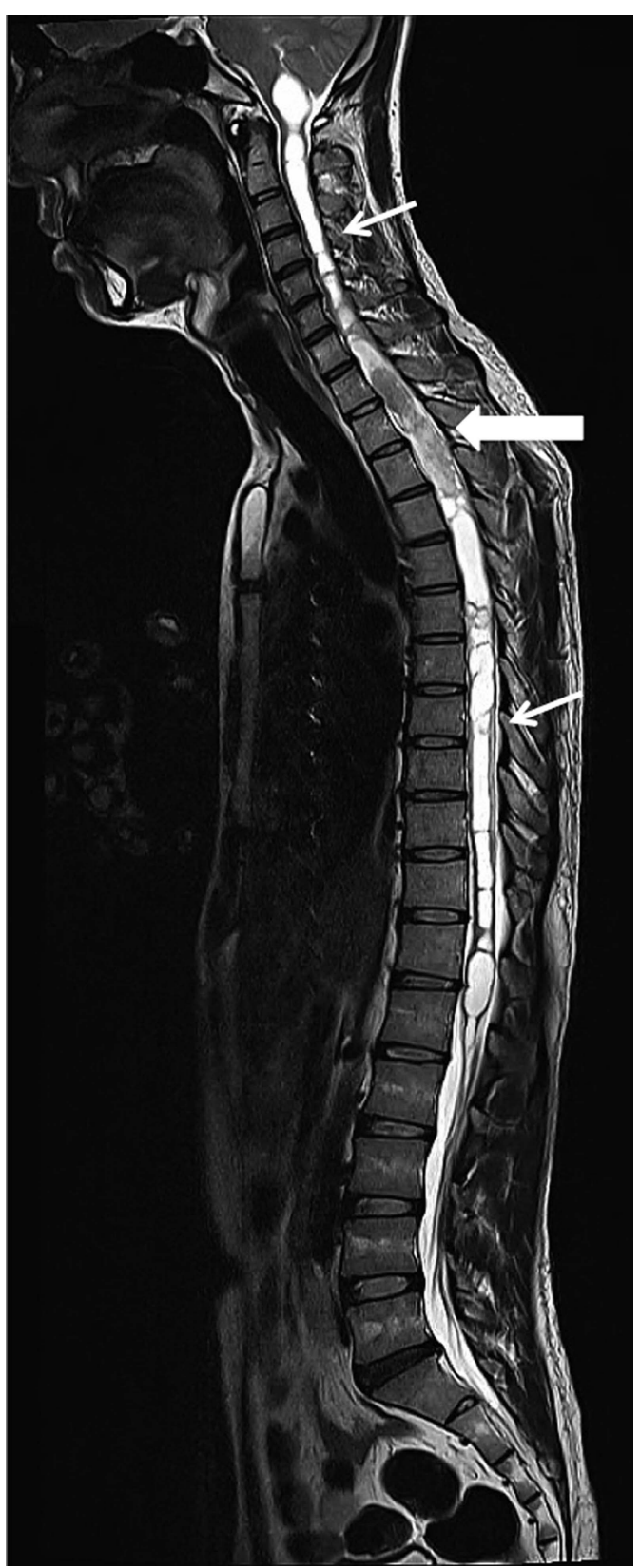

Figure 2 T2-weighted MRI in sagittal plane showing extensive syringohydromyelia involving the entire spinal cord (thin arrow) in association with the spinal neurocytoma (thick arrow). 


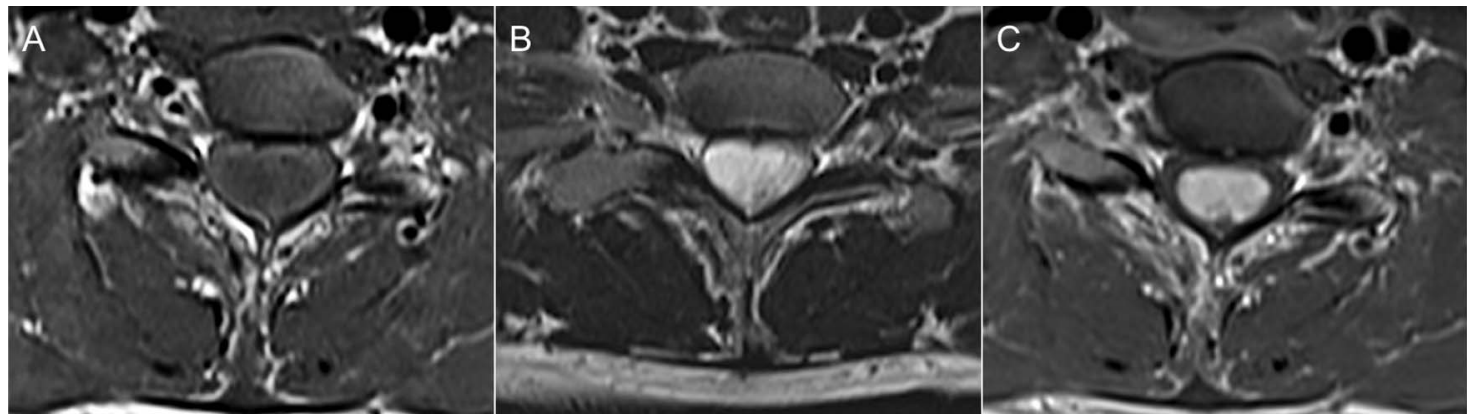

Figure 3 Selected axial MRI of the intramedullary lesion. The lesion is isointense in T1-weighted sequence (A), hyperintense in T2-weighted sequence (B), and avidly enhancing on T1-weighted postgadolinium sequence (C).

associated with an extensive syringohydromyelia involving the entire length of the spinal cord (figure 2). It had irregular but well-demarcated border. The mass was isointense in T1-weighted sequence and hyperintense in T2-weighted sequence (figure 3). There was no extension of the mass into the neural foramina.

A laminectomy at the C6-T3 level was performed and only subtotal resection of the tumour was possible. Intraoperatively, the tumour is attached to the cord with poor tumour-cord interface. A microscopic examination of the resected tumour showed that the tumour cells were composed of mostly uniform round cells with finely speckled chromatin in a fibrillar stroma. Capillary-sized blood vessels were seen in between tumour cells in linear arborising patterns. Some of the vessels were hyalinised. Mitoses were not seen. The immunohistochemical study showed that the tumour cells were positive for synaptophysin and chromogranin A but negative for glial fibrillar acidic protein, cytokeratin, leucocyte common antigen and cluster of differentiation 99 (CD99). A final diagnosis of neurocytoma of the spinal cord was made.

Despite being rare, the present case highlights that spinal neurocytoma is a potential differential diagnosis of an intramedullary spinal cord tumour. On MRI, the lesion is usually hypointense or isointense in T1-weighted images and isointense or hyperintense in T2-weighted images. ${ }^{1}$ The tumour is typically presented as an intramedullary lesion with spinal cord enlargement and it may extend over a few vertebral bodies. An unusual exophytic lesion has also been reported. ${ }^{2}$ In general, it is difficult to differentiate this tumour from more common glial tumours such as ependymoma or astrocytoma based on neuroimaging alone. Only by immunohistochemical profile and ultrastructural characteristic as a neuronal origin can spinal cord neurocytomas be confidently discriminated from the other entities. Strong immunostaining for synaptophysin has been recognised as the most suitable and reliable diagnostic marker. ${ }^{2}$

\section{Learning points}

Spinal neurocytoma is extremely rare.

- Strong immunostaining for synaptophysin is an important diagnostic marker for neurocytoma.

- MRI of the spine is important to characterise a spinal tumour, for surgical planning and for follow-up.

Contributors All of the authors have equal contributions in drafting, writing, revising and completing the manuscript.

Competing interests None.

Patient consent Obtained.

Provenance and peer review Commissioned; internally peer reviewed.

\section{REFERENCES}

1 Polli FM, Salvati M, Miscusi M, et al. Neurocytoma of the spinal cord: report of three cases and review of the literature. Acta Neurochir 2009;151:569-74.

2 Tsai CY, Tsai TH, Lin CH, et al. Unusual exophytic neurocytoma of thoracic spine mimicking meningioma: a case report and review of the literature. Eur Spine J 2011;20:239-42.

Copyright 2013 BMJ Publishing Group. All rights reserved. For permission to reuse any of this content visit

http://group.bmj.com/group/rights-licensing/permissions.

BMJ Case Report Fellows may re-use this article for personal use and teaching without any further permission.

Become a Fellow of BMJ Case Reports today and you can:

- Submit as many cases as you like

- Enjoy fast sympathetic peer review and rapid publication of accepted articles

- Access all the published articles

- Re-use any of the published material for personal use and teaching without further permission

For information on Institutional Fellowships contact consortiasales@bmjgroup.com

Visit casereports.bmj.com for more articles like this and to become a Fellow 